\title{
Assessment of chemical inhibitor addition to improve the gas production from biowaste
}

\author{
Zahedi, S ${ }^{\mathrm{a}, \mathrm{b} *}$; Dahunsi, S.O ${ }^{\mathrm{b}, \mathrm{c}}$; Perez, $\mathrm{M}^{\mathrm{a}}$; Solera, R ${ }^{\mathrm{a}}$; \\ aDepartment of Environmental Technologies, Cadiz University, Spain \\ biomass and Bioenergy Group, Environment and Technology Research \\ Cluster, Landmark University, Nigeria

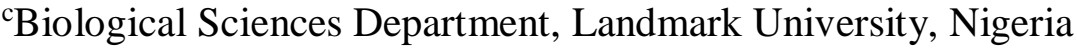 \\ *Corresponding author E-mail address: zahedi.diaz@gmail.com
}

\section{Abstract}

The coexistence of sulphate-reducing bacteria and methanogenic archaea in the reactors during the anaerobic digestion from sulphate-containing waste could favor the accumulation of sulfide on the biogas, and therefore reduce its quality. In this study, the effect of sulphate-reducing bacteria inhibitor $\left(\mathrm{MoO}_{4}^{-2}\right)$ addition in a two phase system from sulphate-containing municipal solid waste to improve the quality of the biogas has been investigated. The results showed that although SRB and sulphide production decreased, the use of inhibitor was not effective to improve the anaerobic digestion in a two phase system from sulphate-containing waste, since a significant decrease on biogas and organic matter removal were observed. Before $\mathrm{MoO}_{4}{ }^{-2}$ addition the average values of volatile solid were around $12 \mathrm{~g} / \mathrm{kg}$, after 5 days of inhibitor use, those values did exceed to $28 \mathrm{~g} / \mathrm{kg}$. Molybdate caused acidification in the reactor and it was according to decrease in the $\mathrm{pH}$ values. In relation to microbial consortia, the effect of inhibitor was a decrease in Bacteria (44\%; 60\% in sulphate-reducing bacteria) and Archaea (38\%) populations.

Keywords: biomethanization; inhibition; sulphate-containing solid waste; microbial community structure. 


\section{Introduction}

Conventional bioconversion of waste in anaerobic digestion (AD) systems is widely recognized (Cuetos et al. 2008; Martín-González et al. 2013; Xing et al. 2014) and is characterized by four steps: hydrolysis, acidogenesis, acetogenesis and methanogenesis. The first three steps are carried out by various bacteria species while the fourth step (methanogenesis) is usually dominated by special microorganisms belonging to the Archaea domain (Zahedi et al. 2016). In the first and second steps, hydrolysis and acidification take place by hydrolytic-acidogenic bacteria $(\mathrm{HAB})$, and intermediate products such as volatile fatty acids (VFA), hydrogen $\left(\mathrm{H}_{2}\right)$ and carbon dioxide $\left(\mathrm{CO}_{2}\right)$ are generated. In the third step, VFA are transformed into acetate, $\mathrm{H}_{2}$ and $\mathrm{CO}_{2}$ by acetogenic bacteria. Usually, Propionate-utilizing acetogens (PUA) and butyrateutilizing acetogens (BUA) are the majority of the acetogens in the anaerobic reactors (Mara and Horan 2003). The methanogens occupy the terminal position in the anaerobic food chain and are normally divided into two main groups based on their substrate conversion capabilities. Acetoclastic methanogens (AUM) are able to convert acetate into methane and carbon dioxide (Montero et al. 2008). Hydrogenotrophic methanogens (HUM) convert $\mathrm{H}_{2} / \mathrm{CO}_{2}$ to methane. These species play a key role in the overall process by maintaining the very low partial pressures of $\mathrm{H}_{2}(<10 \mathrm{~Pa})$ necessary for the functioning of the intermediate trophic group, the acetogens, which are responsible for the conversion of acids organic and alcohol intermediates to direct methane precursors (Montero et al. 2008).

During anaerobic treatment of sulphate-containing wastewaters, sulphate-reducing bacteria (SRB) compete for substrate with other anaerobic bacteria or methanogens. Sulphate competes against organic carbon as an electron acceptor and it leads to the undesirable production of hydrogen sulphide $\left(\mathrm{H}_{2} \mathrm{~S}\right)$. 
$\mathrm{H}_{2} \mathrm{~S}$ is a corrosive gas and its presence reduces the potency of biogas as a fuel for boilers or electricity generation in a biogas engine. Besides, it greatly affects the flammability of biogas when used directly in burners (Rasi et al. 2007; Muñoz et al. 2015). In addition, $\mathrm{H}_{2} \mathrm{~S}$ causes malodor and health hazards due to the well-known toxicity and material corrosion tendencies (Auguet et al. 2015). The nutritional requirements of SRB include an inorganic electron acceptor which is usually provided by sulphate ion and an electron donor which essentially consist of VFA or $\mathrm{H}_{2}$ and occasionally sugars and long chain fatty acids.

Two stages of inhibition exist as a result of sulphate reduction (Chen et al. 2008): (i) primary inhibition due to competition for common organic and inorganic substrates from SRB and (ii) secondary inhibition which results from the toxicity of sulphide to various microbial groups. In this regard, many researchers have used molybdate $\left(\mathrm{MoO}_{4}{ }^{-}\right.$ ${ }^{2}$ ) as sulphide inhibitor where different substrates were utilized (Newport and Nedwell 1988; Tucker et al. 1998; Ranade et al. 1999; Isa and Anderson 2005; Predicala et al. 2008; Rincon et al. 2008; Biswas et al. 2009; Jesus et al. 2015) and all of them show of molybdate successful in inhibiting SRB activity.

Nevertheless, data on the outcome of competition between SRB and the microorganisms mentioned above are contradictory in literature (Chen et al. 2008). The considerable variation in the inhibition/toxicity levels reported for sulphate is due to the complexity of $\mathrm{AD}$ process where mechanisms such as antagonisms, synergism, acclimation and competition could significantly affect the phenomenon of inhibition.

Studies involving use of inhibitors to suppress activity of SRB and, consequently, promote growth of methanogens have been reported in literature (Ranade et al. 1999; Isa and Anderson 2005; Patidar and Tare 2005; Chen et al. 2008). However, other 
studies documented that SRB and methanogens could have a symbiosis between them (Vossoughi et al. 2003; Zahedi et al. 2013a; Auguet et al. 2015), although these organisms are constantly competing as electron acceptors. Therefore, the feasibility of using SRB inhibitor for the control of sulphate reduction and the improvement of methane production in biological reactor are not established.

In view of this, the present study was undertaken to investigate the effect of molybdate supplementation on the two-phase dry-thermophilic AD process of sulphate-containing municipal solid waste. Structure and dynamics of the anaerobic consortia developed along the experiment were analyzed by fluorescent in situ hybridization (FISH) employing different oligonucleotide probes.

\section{Methods}

\subsection{Experimental equipment}

Two laboratory-scale continuously stirred tank reactors were employed (Figure 1). The first reactor, dedicated to the hydrogen production (HP) (first phase), had a 5.5 liters working volume, while the second reactor (second phase) dedicated to the methane production (MP) had a 5 liters working volume, both heated by recirculating water through a thermostatic jacket. PRECISTERM 6000142/6000389 (SELECTA S.A.) baths were used, with a maximum capacity of 7 liters of water. The stainless steel reactors lid have a diameter of $200 \mathrm{~mm}$ and contain three openings, one for the biogas outlet, a feed inlet and another opening for the stirring system. The bottoms of the reactors had a discharge valve with a $40 \mathrm{~mm}$ i.d., used for sampling. The biogas was collected in 40 liter capacity Tedlar (a polyvinyl fluoride plastic polymer) bags. The stirring systems consisted of an IKA EUROSTAR Power Control visc-P4 overhead stirrer coupled to a stainless steel blade with scrapers which allows homogenization of 
the waste at a speed of $23 \mathrm{rpm}$. The system was fed semi-continuously, once per day, and the hydraulic retention times (HRT) were 1.5 (organic loading rate $(\mathrm{OLR})=57$ $\mathrm{g} / \mathrm{l} / \mathrm{d})$ and $5 \mathrm{~d}(\mathrm{OLR}=8 \mathrm{~g} / \mathrm{l} / \mathrm{d})$ for the first and second phase, respectively.

\subsection{Inoculum, substrate and feeding}

The seed used as acidogenic and methanogenic inoculum were collected from a two phase dry-thermophilic system of urban wastes. The total solid (TS) and volatile solid (VS) concentrations in the second phase (methanogenic inoculum) were $67 \mathrm{~g} / \mathrm{kg}$ and 33 $\mathrm{g} / \mathrm{kg}$ as against their concentrations in the first phase (acidogenic inoculum) which were $82 \mathrm{~g} / \mathrm{kg}$ and $50 \mathrm{~g} / \mathrm{kg}$, respectively.

The tested substrate in the first phase was the urban wastes from the $30 \mathrm{~mm}$ trommel of the municipal solid waste treatment plant in Cadiz, Spain. The urban wastes was stored in $25 \mathrm{~kg}$ drums at $-4^{\circ} \mathrm{C}$ to avoid $\mathrm{AD}$ by the microorganisms found in the solid waste itself (Zahedi et al. 2013b). The TS concentration of the feed of the first reactor was adjusted to $20 \%$ (which is characteristic of dry AD) by adding tap water. Composition of the substrate (urban solid wastes and water; $20 \%$ of TS) employed in the first phase is shown in Table 1. The substrate used in the second phase was the effluent of the first phase (Table 2). Both reactors were fed once a day (semi-continuous).

\subsection{Inhibitor treatment methodology}

The effect of continuous dosing molybdate $\left(\mathrm{MoO}_{4}^{-2}\right)(2.5 \mathrm{mM})$ to improve the performance in two-phase dry-thermophilic $\mathrm{AD}$ of sulphate-containing urban waste was realized. No molybdate was added to the first phase, because under acid conditions the biogas was sulphide-free (Zahedi et al. 2013b). The whole experiment length was $50 \mathrm{~d}$.

During the first $45 \mathrm{~d}$ no inhibitor was used. In these 45 days two different period were considered: startup (0-20 d) and control/stationary phase (20-45 d). On day 46, sodium 
molybdate (MW=205.92 g/mol), $2.6 \mathrm{~g}$, was added to the digester so as to have $2.5 \mathrm{mM}$ concentration of the inhibitor in the reactor ( $V=5$ 1) (Isa and Anderson 2005). From next day onwards, i.e. from day 47, based on the daily wash out, $0.52 \mathrm{~g}$ per $1000 \mathrm{ml}$ of daily feed was added every day, so as to maintain the $2.5 \mathrm{mM}$ inhibitor concentration in the digester.

\subsection{Analytical methods}

Total and soluble chemical oxygen demand (TCOD, SCOD), alkalinity, sulphate, VS, $\mathrm{pH}$ and VFA were performed according to previous studies (Zahedi et al. 2013c; Dahunsi et al. 2016a,b). Determination of total and partial alkalinity and ammonia $\left(\mathrm{NH}_{4}{ }^{+}-\mathrm{N}\right)$ were carried out daily. Fluctuation in the concentration of volatile fatty acids (VFA) was determined using a gas chromatography (GC2010) to which was attached a Fused Silica Capillary Column (Supelco NUKOLTM, 15 × 0.53 x $0.5 \mu \mathrm{m}$ film thickness) and with a flame ionization detector $\left(200^{\circ} \mathrm{C}\right)$ with $\mathrm{H}_{2}$ as the carrier gas. An initial temperature of $80^{\circ} \mathrm{C}$ was used and was subsequently increased to $140^{\circ} \mathrm{C}$, then $160^{\circ} \mathrm{C}$ and finally to $200^{\circ} \mathrm{C}$ at a rate of $10^{\circ} \mathrm{C} / \mathrm{min}$. The analyzed samples were centrifuged and filtered through a $0.45 \mu \mathrm{m}$ membrane.

Production of gas was continuously measured using a gas flow meter (Ritter Company, drum-type wet-test volumetric gas meters), and the composition of the produced gas was determined by gas chromatography separation (SHIMADZU GC-2010). $\mathrm{H}_{2}, \mathrm{CH}_{4}$, $\mathrm{CO}_{2}, \mathrm{O}_{2}$ and $\mathrm{N}_{2}$ were analyzed by means of a thermal conductivity detector (TCD) employing a Supelco Carboxen 1010 Plot column. Samples were taken using a $1 \mathrm{ml}$ Dynatech Gastight gas syringe under the following operating conditions: split $=100$; constant pressure in the injection port $(70 \mathrm{kPa}) ; 2$ min at $40{ }^{\circ} \mathrm{C}$; ramped at $40{ }^{\circ} \mathrm{C} / \mathrm{min}$ until $200^{\circ} \mathrm{C} ; 1.5 \mathrm{~min}$ at $200^{\circ} \mathrm{C}$; detector temperature: $250^{\circ} \mathrm{C}$; and injector temperature: 
$200^{\circ}$ C. Helium was used as carrier gas $(266.2 \mathrm{ml} / \mathrm{min}$ ) (Zahedi et al. 2017b) .

152 Commercial mixtures of $\mathrm{H}_{2}, \mathrm{CH}_{4}, \mathrm{CO}_{2}, \mathrm{O}_{2}, \mathrm{~N}_{2}$ and $\mathrm{H}_{2} \mathrm{~S}$ (Abelló Linde S.A.) were used to calibrate the system.

\subsection{Microbiological analysis and biochemical activity}

The cellular concentration and percentages of Bacteria and Archaea were quantified by epifluorescence method (FISH) according to the method of Zahedi et al. (Zahedi et al. 2013c; Zahedi et al. 2017a). The main steps of FISH of whole cells using 16S rRNAtargeted oligonucleotide probes are cell fixation, permeabilisation and hybridisation with the desired probe(s).

The cellular concentration and percentages of Eubacteria, Archaea, BUA, PUA, SRB, HUM and AUM were obtained by FISH according to Zahedi et al.(Zahedi et al. 2013c; Zahedi et al. 2014). The total population was calculated as the sum of the relative amounts of Eubacteria and Archaea, because the main anaerobic groups in the anaerobic reactors are contained within these two domains (Griffin et al. 1998). Acetogens were calculated as the sum of the relative amounts of PUA and BUA. HAB were calculated as the difference in the relative amounts of Eubacteria and acetogens.

\section{Results and discussion}

The process performances and the functional Bacteria and Archaea community structures of the two-phase anaerobic reactors for HP and MP were investigated and analyzed together. The section has been structured into two parts: hydrogenic phase performance and methanogenic phase performance.

3.1 Hydrogenic phase performance

As commented before, no molybdate was added to the first phase, because the biogas was sulphide-free. The characterization physical-chemical and microbiological in the 
effluent of the first phase are shown in the Table 2. The performance in the first phase was according to Zahedi et al.(Zahedi et al. 2013c) study to $1.5 \mathrm{~d}$ HRT. This $\mathrm{pH}$ value was close to the ideal $\mathrm{pH}$ conditions for HP of 5.5 (Bolzonella et al. 2012). VFA composition was composed mainly of butyric acid $(5.1 \pm 0$. g/l). The dominant fermentation products were butyric acid and acetic acid with small amounts of propionic also detected $(<0.1 \mathrm{~g} / \mathrm{l})$. The sulphate values in the effluent were the same with those measured in the feeding; therefore no sulphate consumption was detected (no SBR activity was detected). A high solubilization (increase in SCOD and VFA and decrease in VS) was detected. The butyrate acid concentration was higher than acetic acid concentration and it was in line to other researches of hydrogen production from similar wastes (Cadiz-Spain urban wastes) (Romero Aguilar et al. 2013; Zahedi et al. 2013b; Angeriz-Campoy et al. 2017; Zahedi et al. 2017a). The ratio of butyrate:acetate ( $\mathrm{g}$ butyrate/g acetate) was 2.5 and it according to the ratios reported by these previous studies. The biogas produced was composed of $\mathrm{H}_{2}$ and $\mathrm{CO}_{2}$ without $\mathrm{CH}_{4}$ and $\mathrm{H}_{2} \mathrm{~S}$ detection. In terms of yields, biohydrogen in the first reactor was $47 \pm 4 \%$ and the HP was $\left.2.0 \pm 0.3 \mathrm{~L} \mathrm{H}_{2} / 1 / \mathrm{d}\right)$.

\subsection{Methanogenic phase performance}

\subsubsection{Process stability}

The stability of the process was evaluated based on the evolution of $\mathrm{pH}$ and the VFA/alkalinity ratio (VFA/Alk) before (1-45 d) and after (45-50 d) SRB inhibitor addition (Siles Lopez et al. 2009).

Fig. 2.a shows the evolution of $\mathrm{pH}$ throughout the test. At the beginning (before inhibitor addition) the systems were able to self-regulate and reach a $\mathrm{pH}$ of between 7.0 and 8.5, the optimal $\mathrm{pH}$ for the activity of methanogens (De La Rubia et al. 2009; 

showing microbial inhibition of $\mathrm{H}_{2}$ and acid consumer organisms.

202 Alkalinity is the capacity to neutralise acids, the total volatile fatty acids (TVFA)/Alk ratio being typically used as a measurement to evaluate anaerobic system stability (Balaguer et al. 1992; Rincón et al. 2008; Siles Lopez et al. 2009). Values between 0.1 and 0.4 (equiv. acetic acid/equiv. $\mathrm{CaCO}_{3}$ ) indicate favourable operating conditions without the risk of acidification. The evolution of these ratios is shown in Fig 2.b. Before inhibitor addition stability was observed, however from the day after the molybdate was added this ratio decline sharply, demonstrating the non-stability of the second phase (ratios were higher than 0.4 ). Therefore, the $\mathrm{pH}$ values and the acids gathered, thus preventing the activity of the methanogens, as will be explained later.

\subsubsection{Process performances}

The highest values for the removal of VS $(81 \pm 7 \%)$ and SCOD $(58 \pm 2 \%)$ were obtained before inhibitor addition. These values were similar to those obtained by Brownie (Browne et al. 2014) in biomethane production from the organic fraction of municipal solids waste in semi-continuous systems. Before $\mathrm{MoO}_{4}{ }^{-2}$ addition the average values of SCOD and VS in the effluent were around $9 \mathrm{~g} / \mathrm{l}$ and $12 \mathrm{~g} / \mathrm{kg}$ respectively, after $\mathrm{MoO}_{4}{ }^{-2}$ inhibition on day 50 those values did exceed to $25 \mathrm{~g} / \mathrm{l}$ and $28 \mathrm{~g} / \mathrm{kg}$ respectively (Figure 3). The reduction in the consumption of the organic matter means inhibition of the anaerobic digestion process.

In relation to VFA, the effect of molybdate was an acidification in the reactor (increase in acid content, Figure 4) according to decrease in the $\mathrm{pH}$ values. In the present research, before molybdate addition, the concentrations of VFA were in the order propionic >acetic > butyric. Addition of molybdate caused butyric and acetic acids to 
dominate over propionic acid at the end of the trial. The presence of acetic acid in the effluent shows that non-availability of AUM substrate was not the underlying problem for the inhibition of $\mathrm{CH}_{4}$ production in these studies, but chronic inhibition of AUM by $\mathrm{MoO}_{4}^{-2}$. In addition, butyric increment in the effluent was resulted of the nonavailability to the BUA to consume the butyric. The amount of propionic acid generated after molybdate addition was similar to the amount produced before of inhibitor addition, suggesting that acetogenic activity of PUA was sufficient to achieve the normal propionic acid concentrations(Zahedi et al. 2013a).

It can clearly be observed that the addition of sodium molybdate on day 45 caused immediate inhibition of sulphate reduction, thereby resulting in increase of sulphate content in the effluent (Figure 5) and total absence of $\mathrm{H}_{2} \mathrm{~S}$ in the biogas (Figure 6a) on the following day. Before $\mathrm{MoO}_{4}^{-2}$ addition the average values of sulphate were around $0.7 \mathrm{~g} / \mathrm{l}$ and on day 50 those values increased to $2.0 \mathrm{~g} / \mathrm{l}$. The values of $\mathrm{H}_{2} \mathrm{~S}$ decreased from $45 \pm 5 \mathrm{~mL} \mathrm{H}_{2} \mathrm{~S} / \mathrm{l} / \mathrm{d}$ on day 45 to $0 \mathrm{~mL} \mathrm{H}_{2} \mathrm{~S} / \mathrm{l} / \mathrm{d}$ on day 46 . Regarding to the $\mathrm{MP}$, the values of the MP also involved a decrease due to inhibitor use (Figure 6b). Before the use of the SRB inhibitor, MP was around 3.5 $\mathrm{L} \mathrm{CH}_{4} / 1 / \mathrm{d}$ and after the supplement it was modestly decreased, until the end, where MP did not exceed $0.2 \mathrm{~L} \mathrm{CH}_{4} / 1 / \mathrm{d}$ (day 50). It smaller amounts of inhibitor added in increasing increments and the observed return of the system to the previous rate of biogas production and quality.

\subsubsection{Microbial community}

The evolution of the main microbial group involved in the methanogenic process is described in the Table 3. In the present research, concentrations of different microbial 
groups were evaluated before and after inhibitor addition. All the results shown are average values. Before inhibitor addition, the ratio of Eubacteria: Archaea was 55:45. These results are in accordance to those obtained by Zahedi et al.(Zahedi et al. 2013c) in the second phase reactor of dry-thermophilic anaerobic digestion process of sulphatecontaining municipal solid waste and logically, lower than those obtained by Griffin et al.(Griffin et al. 1998) and McMahon et al.(McMahon et al. 2001) in single-phase reactors of organic waste. SRB population values were in line with those (20-28\%) obtained by Zahedi et al.(Zahedi et al. 2013c) and Zhang et al.(Zhang et al. 2011) lower than those (14\%) obtained by Mohan et al.(Mohan et al. 2005).

It should be noted, that after inhibitor addition the microbial proportion in the reactor had not very altered, the microbial consortia and microbial activity were hardly altered. It is necessary to emphasize that although the proportion of microorganisms in the reactor is a key, not only the stability, but also the adequate dynamics ("flexibility") of the microbial community structure and high values of microbial activity are important for the stable performance of the reactors treating urban wastes ${ }^{13}$.

At the end of the trial, the microbial consortia were decreased in $42 \%$. The removal rates of Bacteria, Archaea, HAB, acetogens, AUM, HUM, SRB, BUA and PUA were $44 \%, 38 \%, 48 \%, 39 \%, 35 \%, 41 \%, 60 \%, 63 \%$ and $15 \%$ respectively. The most affected were SRB and BUA and the most resistant group was PUA which is in line with the constant values of propionic acid in the effluent. The reductions in the microbial consortia, the decrease in the MP, $\mathrm{H}_{2} \mathrm{~S}$ production, $\mathrm{pH}$ value, and increase in the sulphate, VS, SCOD and VFA contents all reveal a decrease in the microbial activity, except for PUA. 
271 In short, the use of the toxic to improve the biogas of the two-phase dry-thermophilic

272

273

274

275

276

277

278

279

280

281

282

283

284

285

286

287

288

289

290

291

292

293

294

\section{2} anaerobic digestion process of sulphate-containing municipal solid is not effective. However, it is to be noted that the harmful effect of molybdate supplementation on the SRB and methanogens and therefore, on the $\mathrm{H}_{2} \mathrm{~S}$ and $\mathrm{CH}_{4}$ generation makes this treatment an interesting option on other fields, as sewerage system. Since, anaerobic conditions in sewer pipes favor the accumulation of both $\mathrm{H}_{2} \mathrm{~S}$ and $\mathrm{CH}_{4}$ and these compounds have detrimental effects on the sewer system, with different consequences for both the installation and its surroundings (Auguet et al. 2015) (such as malodor, health hazards due to the well-known toxicity of $\mathrm{H}_{2} \mathrm{~S}$, and corrosion of both the inner surface of pipes and the inlet zones of waste water treatment plants, etc)

\section{Conclusion}

Inhibitor addition has proven successful to remove the undesirable production of hydrogen sulphide $\left(\mathrm{H}_{2} \mathrm{~S}\right)$. However it too resulted in an increase in TVFA/Alk ratio, as well as decrease in $\mathrm{pH}$, organic removal organic matter and biogas generation. All this indicated inhibition of all the steps to $\mathrm{AD}$ (except to propionic degradation). Therefore, although molybdate is an effective bactericide for SRB, the use of the toxic would be avoided, since molybdate supplementation did not improve the quality of the biogas, under the circumstances of this experiment. Microbial consortia were decreased in 42\%. The removal rates of Bacteria, Archaea, HAB, acetogens, AUM, HUM, SRB, BUA and PUA were $44 \%, 38 \%, 48 \%, 39 \%, 35 \%, 41 \%, 60 \%, 63 \%$ and $15 \%$ respectively. 
Zahedi thanks MIFAS association for people with physical disabilities, especially R.

297 Ferrer and J.Amores (Olot, Girona, Spain).

298

The authors wish to express their gratitude to Spanish Ministry of Economy and

Competitiveness, specifically to the Project CTM 2015-64810R financed by the

European Regional Development Fund (ERDF) entitled "Hydrogen-Methane

Production from Biosolids and Vinasses Anaerobic Co-Digestion”.

302

303

\section{References}

304

305

306

307

308

309

310

311

Angeriz-Campoy R, Fdez.-Güelfo LA, Alvarez-Gallego C, Romero LI (2017) New criteria to determine the destabilization of the acidogenic anaerobic co-digestion of organic fraction of municipal solid waste.

Auguet O, Pijuan M, Batista J, Borrego CM, Gutierrez O (2015) Changes in microbial biofilm communities during colonization of sewer systems. Applied and Environmental Microbiology 81:7271-7280. doi: 10.1128/AEM.01538-15

Balaguer MD, Vicent MT, París JM (1992) Anaerobic fluidized bed reactor with sepiolite as support for anaerobic treatment of vinasse. Biotechnology Letters 14:433-438. doi: 10.1007/BF01021260

Biswas KC, Woodards NA, Xu H, Barton LL (2009) Reduction of molybdate by sulfate-reducing bacteria. Biometals 22:131-139.

Bolzonella D, Cavinato C, Fatone F, Pavan P, Cecchi F (2012) High rate mesophilic, thermophilic, and temperature phased anaerobic digestion of waste activated sludge: A pilot scale study. Waste Management 32:1196-1201. doi: 10.1016/j.wasman.2012.01.006 
Browne JD, Allen E, Murphy JD (2014) Assessing the variability in biomethane production from the organic fraction of municipal solid waste in batch and continuous operation. Applied Energy 128:307-314. doi: 10.1016/j.apenergy.2014.04.097

Chen Y, Cheng JJ, Creamer KS (2008) Inhibition of anaerobic digestion process: A review. Bioresource Technology 99:4044-4064. doi: 10.1016/j.biortech.2007.01.057

Cuetos MJ, Gomez X, Otero M, Morin A (2008) Anaerobic digestion of solid slaughterhouse waste (SHW) at laboratory scale: Influence of co-digestion with the organic fraction of municipal solid waste (OFMSW). Biochemical Engineering Journal 40:99-106. doi: 10.1016/j.bej.2007.11.019

Dahunsi SO, Oranusi S, Owolabi JB, Efeovbokhan VE (2016) Mesophilic anaerobic codigestion of poultry dropping and Carica papaya peels: Modelling and process parameter optimization study. Bioresource Technology. doi: 10.1016/j.biortech.2016.05.118

Dahunsi, S.O.; Oranusi, S.; Owolabi, J.B.; Efeovbokhan, V.E. Comparative biogas generation from fruit peels of Fluted Pumpkin (Telfairia occidentalis) and its optimization. Bioresource Technology 2016, 221, 517-525.

De La Rubia MA, Raposo F, Rincon B, Borja R (2009) Evaluation of the hydrolyticacidogenic step of a two-stage mesophilic anaerobic digestion process of sunflower oil cake. Bioresource Technology 100:4133-4138. doi: 10.1016/j.biortech.2009.04.001 
dynamics during start-up of anaerobic digesters treating municipal solid waste and biosolids. Biotechnology and Bioengineering 57:342-355.

Isa MH, Anderson GK (2005) Molybdate inhibition of sulphate reduction in two-phase anaerobic digestion. Process Biochemistry 40:2079-2089. doi: 10.1016/j.procbio.2004.07.025

Jesus EB, Andrade Lima LRP, Bernandez LA, Almeida PF (2015) Inhibition of microbial sulfate reduction by molybdate. Braz Pet Gas 9:95-106.

Mara D, Horan N (2003) Handbook of Water and Wastewater Microbiology. Academic Press-Elsevier, London

Martín-González L, Font X, Vicent T (2013) Alkalinity ratios to identify process imbalances in anaerobic digesters treating source-sorted organic fraction of municipal wastes. Biochemical Engineering Journal 76:1-5. doi: 10.1016/j.bej.2013.03.016

McMahon KD, Stroot PG, Mackie RI, Raskin L (2001) Anaerobic codigestion of municipal solid waste and biosolids under various mixing conditions-II: Microbial population dynamics. Water Research 35:1817-1827. doi: 10.1016/S00431354(00)00438-3

Mohan SV, Rao NC, Prasad KK, Sarma PN (2005) Bioaugmentation of an anaerobic sequencing batch biofilm reactor (AnSBBR) with immobilized sulphate reducing bacteria (SRB) for the treatment of sulphate bearing chemical wastewater. Process Biochemistry 40:2849-2857. doi: 10.1016/j.procbio.2004.12.027

Montero B, Garcia-Morales JL, Sales D, Solera R (2008) Evolution of microorganisms in thermophilic-dry anaerobic digestion. Bioresource Technology 99:3233-3243. 
doi: 10.1016/j.biortech.2007.05.063

Muñoz R, Meier L, Diaz I, Jeison D (2015) A review on the state-of-the-art of physical/chemical and biological technologies for biogas upgrading. Reviews in Environmental Science and Biotechnology 14:727-759. doi: 10.1007/s11157-0159379-1

Newport P, Nedwell D (1988) The mechanisms of inhibition of Desulfovibrio and Desulfotomaculum species by selenate and molybdate. J Appl Bacteriol 65:419423.

Patidar SK, Tare V (2005) Effect of molybdate on methanogenic and sulfidogenic activity of biomass. Bioresource Technology 96:1215-1222.

Predicala B, Nemati M, Stade S, Lague C (2008) Control of H2S emission from swine manure using Na-nitrate and Na-molybdate. Journal Hazerd Mater 154:300-309.

Ranade DR, Dighe AS, Bhirangi SS, Panhalka VS, Yeole T. (1999) Evaluation of the use of sodium molybdate to inhibit sulphate reduction during anaerobic digestion of distillery waste. Bioresource Technology 68:287-291.

Rasi S, Veijanen A, Rintala J (2007) Trace compounds of biogas from different biogas production plants. Energy 32:1375-1380. doi: 10.1016/j.energy.2006.10.018

Rincón B, Borja R, González JM, Portillo MC, Sáiz-Jiménez C (2008) Influence of organic loading rate and hydraulic retention time on the performance, stability and microbial communities of one-stage anaerobic digestion of two-phase olive mill solid residue. Biochemical Engineering Journal 40:253-261. doi: 10.1016/j.bej.2007.12.019 
Rincon JRT, Gomez DMC, Caraballo AES, Alvarez JHP (2008) Evaluacion del molibdato y nitrato sobre bacterias sulfato-reductoras asociadas a procesos de corrosion em sistemas industriales. Reve Argent Microbiol 52-62.

Romero Aguilar MA, Fdez-Guelfo LA, Alvarez-Gallego CJ, Romero García LI (2013) Effect of HRT on hydrogen production and organic matter solubilization in acidogenic anaerobic digestion of OFMSW. Chemical Engineering Journal 219:443-449. doi: 10.1016/j.cej.2012.12.090

Siles Lopez JA, Martin Santos M de los A, Chica Perez AF, Martín Martín A (2009) Anaerobic digestion of glycerol derived from biodiesel manufacturing. Bioresource Technology 100:5609-5615. doi: 10.1016/j.biortech.2009.06.017

Tucker M, Barton L, Thomson B (1998) Removal of U and Mo from water by immobilized Desulfovibrio desulfuricans in column reactors. Biotechnology and Bioengineering 60:88-96.

Vossoughi M, Shakeri M, Alemzadeh I (2003) Performance of anaerobic baffled reactor treating synthetic wastewater influenced by decreasing COD/SO4 ratios. Chemical Engineering and Processing: Process Intensification 42:811-816. doi: $10.1016 / \mathrm{S} 0255-2701(02) 00107-1$

Xing W, Chen X, Zuo J, Wang C, Lin J, Wang K (2014) A half-submerged integrated two-phase anaerobic reactor for agricultural solid waste codigestion. Biochemical Engineering Journal 88:19-25. doi: 10.1016/j.bej.2014.03.016

Zahedi S, García-Morales JL, Sales D, Solera R (2017a) Bioenergy Generation from Municipal Solid Waste and Glycerin Waste: Population Dynamics. Energy and Fuels. doi: 10.1021/acs.energyfuels.7b01526 
Zahedi S, Sales D, Romero LI, Solera R (2013a) Optimisation of single-phase drythermophilic anaerobic digestion under high organic loading rates of industrial municipal solid waste: Population dynamics. Bioresource Technology 146:109_ 117.

Zahedi S, Sales D, Romero LI, Solera R (2013b) Hydrogen production from the organic fraction of municipal solid waste in anaerobic thermophilic acidogenesis: Influence of organic loading rate and microbial content of the solid waste. Bioresource Technology 129:85-91. doi: 10.1016/j.biortech.2012.11.003

Zahedi S, Sales D, Romero LI, Solera R (2013c) Optimisation of the two-phase drythermophilic anaerobic digestion process of sulphate-containing municipal solid waste: Population dynamics. Bioresource Technology 148:443-452.

Zahedi S, Sales D, Romero LI, Solera R (2014) Dark fermentation from real solid waste. Evolution of microbial community. Bioresource Technology 151:221-226. doi: 10.1016/j.biortech.2013.10.063

Zahedi S, Solera R, García-Morales JL, Ennouri H, Sales D (2017b) Evaluation of the effect of glycerol supplementation on the anaerobic digestion of real municipal solid waste in batch mode. Fuel 193:15-21. doi: 10.1016/j.fuel.2016.12.024

Zahedi S, Solera R, Micolucci F, Cavinato C, Bolzonella D (2016) Changes in microbial community during hydrogen and methane production in two-stage thermophilic anaerobic co-digestion process from biowaste. Waste Management 49:40-46. doi: 10.1016/j.wasman.2016.01.016

Zhang J, Zhang Y, Quan X, Liu Y, An X, Chen S, Zhao H (2011) Bioaugmentation and functional partitioning in a zero valent iron-anaerobic reactor for sulfate-containing 
435 10.1016/j.cej.2011.08.069

436

437 
Table 1. Physical-chemical and microbiological characterization of the substrate employed in the first phase.

441

\begin{tabular}{|c|c|}
\hline Parameter & Value \\
\hline pH & $5.3(0.6)$ \\
\hline TS (g/l) & $120(15)$ \\
\hline VS (g/l) & $85(7)$ \\
\hline Sulphate (g/l) & $1.9(0.3)$ \\
\hline VFA (g acetic acid/l) & $1.8(0.5)$ \\
\hline Acetate (g/l) & $1.87(0.5)$ \\
\hline Propionate (g/l) & $0.0(0.0)$ \\
\hline Butyrate (g/l) & $0.4(0.2)$ \\
\hline Total population $\left(10^{8}\right.$ cells $\left./ \mathrm{ml}\right)$ & $6(2)$ \\
\hline Eubacteria (\%) & $78(3)$ \\
\hline Archaea (\%) & $22(2)$ \\
\hline
\end{tabular}

442

Average values are shown, with standard deviations in parentheses. 
Table 2: Physicochemical and microbiological characterization of the first phase reactor effluent

Physicochemical parameters

\begin{tabular}{ccccccccc}
\hline pH & $\begin{array}{c}\text { SCOD } \\
(\mathbf{g} / \mathbf{l})\end{array}$ & $\begin{array}{c}\text { VS } \\
(\mathbf{g} / \mathbf{k g})\end{array}$ & $\begin{array}{c}\text { Alkalinity } \\
\left(\mathbf{g C a C O}_{3} / \mathbf{l}\right)\end{array}$ & $\begin{array}{c}\text { Sulphate } \\
(\mathbf{g} / \mathbf{l})\end{array}$ & $\begin{array}{c}\text { TVFA } \\
(\mathbf{g} \text { acetic/l) }\end{array}$ & $\begin{array}{c}\text { Acetic } \\
(\mathbf{g} / \mathbf{l})\end{array}$ & $\begin{array}{c}\text { Propionic } \\
(\mathbf{g} / \mathbf{l})\end{array}$ & $\begin{array}{c}\text { Butyric } \\
(\mathbf{g} / \mathbf{l})\end{array}$ \\
\hline $5.3 \pm 0.3$ & $33 \pm 2$ & $42 \pm 5$ & $4 \pm 0$ & $1.9 \pm 0.2$ & $10.4 \pm 0.9$ & $2.5 \pm 0.4$ & $0.1 \pm 0.1$ & $5.1 \pm 0.5$ \\
\hline
\end{tabular}

Microbiological parameters

\begin{tabular}{ccccccccc}
\hline $\begin{array}{c}\text { Total } \\
\text { population } \\
\left(\mathbf{1 0}^{\mathbf{8}} \text { cells/mL) }\right.\end{array}$ & $\begin{array}{c}\text { Eubacteria } \\
(\boldsymbol{\%})\end{array}$ & $\begin{array}{c}\text { HAB } \\
(\boldsymbol{\%})\end{array}$ & $\begin{array}{c}\text { Acetogens } \\
(\boldsymbol{\%})\end{array}$ & $\begin{array}{c}\text { BUA } \\
(\boldsymbol{\%})\end{array}$ & $\begin{array}{c}\text { PUA } \\
(\boldsymbol{\%})\end{array}$ & $\begin{array}{c}\text { SRB }^{\mathbf{2}} \\
(\boldsymbol{\%})\end{array}$ & $\begin{array}{c}\text { Archaea } \\
(\boldsymbol{\%})\end{array}$ & $\begin{array}{c}\text { AUM } \\
(\boldsymbol{\%})\end{array}$ \\
\hline $9.5 \pm 0.6$ & $88 \pm 2$ & $70 \pm 2$ & $18 \pm 2$ & $8 \pm 1$ & $10 \pm 1$ & $14 \pm 1$ & $12 \pm 1$ & $5 \pm 0$
\end{tabular}


451 Table 3: Microbiological characterization of the second phase reactor effluent.

\begin{tabular}{|c|c|c|c|c|c|c|}
\hline \multirow[b]{2}{*}{ Parameter } & \multicolumn{6}{|c|}{ Period (Day) } \\
\hline & $1-45^{*}$ & 46 & 47 & 48 & 49 & 50 \\
\hline \multicolumn{7}{|c|}{ Microbiological parameters } \\
\hline Total population $\left(10^{8}\right.$ cells $\left./ \mathrm{mL}\right)$ & $21.8 \pm 2.5$ & 16.3 & 14.5 & 14.9 & 13.9 & 12.8 \\
\hline Eubacteria $(\%)$ & $55 \pm 2$ & 56 & 63 & 51 & 49 & 53 \\
\hline НАВ (\%) & $28 \pm 1$ & 34 & 37 & 27 & 25 & 25 \\
\hline Acetogens (\%) & $27 \pm 2$ & 22 & 26 & 24 & 24 & 28 \\
\hline BUA & $14 \pm 1$ & 6 & 9 & 8 & 7 & 9 \\
\hline PUA $(\%)$ & $13 \pm 1$ & 16 & 17 & 16 & 17 & 19 \\
\hline $\operatorname{SRB}^{\mathrm{a}}(\%)$ & $26 \pm 2$ & 18 & 18 & 16 & 17 & 18 \\
\hline Archaea $(\%)$ & $45 \pm 2$ & 44 & 37 & 49 & 51 & 48 \\
\hline $\operatorname{AUM}(\%)$ & $24 \pm 1$ & 24 & 21 & 29 & 28 & 27 \\
\hline HUM (\%) & $21 \pm 1$ & 20 & 15 & 21 & 23 & 21 \\
\hline
\end{tabular}

452 aPercentages compared to total Eubacteria.

$453 *$ Values corresponding to the analytical determinations in steady conditions (between day 21 and 45).

454 


\section{$455 \quad$ Figure Captions}

456 Figure 1: The laboratory-scale reactors used in this study. Hydrogenic reactor to the left 457 and methanogenic reactor to the right.

458 Figure 2: (a) $\mathrm{pH}$ evolution. (b) TVFA/Alk evolution (g acetic/g $\mathrm{CaCO}_{3}$ )

459 Figure 3: (a) SCOD evolution (g/l). (b) Volatile Solid evolution (g/kg).

460 Figure 4: (a) VFA evolution (g/l).

461 Figure 5: (a) Sulphate evolution (g/l).

462 Figure 6: (a) Sulphide production (SP) evolution $\left(\mathrm{ml} \mathrm{H}_{2} \mathrm{~S} / \mathrm{l} / \mathrm{d}\right)$. (b) Methane production 463 (MP) evolution $\left(\mathrm{l} \mathrm{CH}_{4} / \mathrm{l} / \mathrm{d}\right)$. 
465 Figure 1.

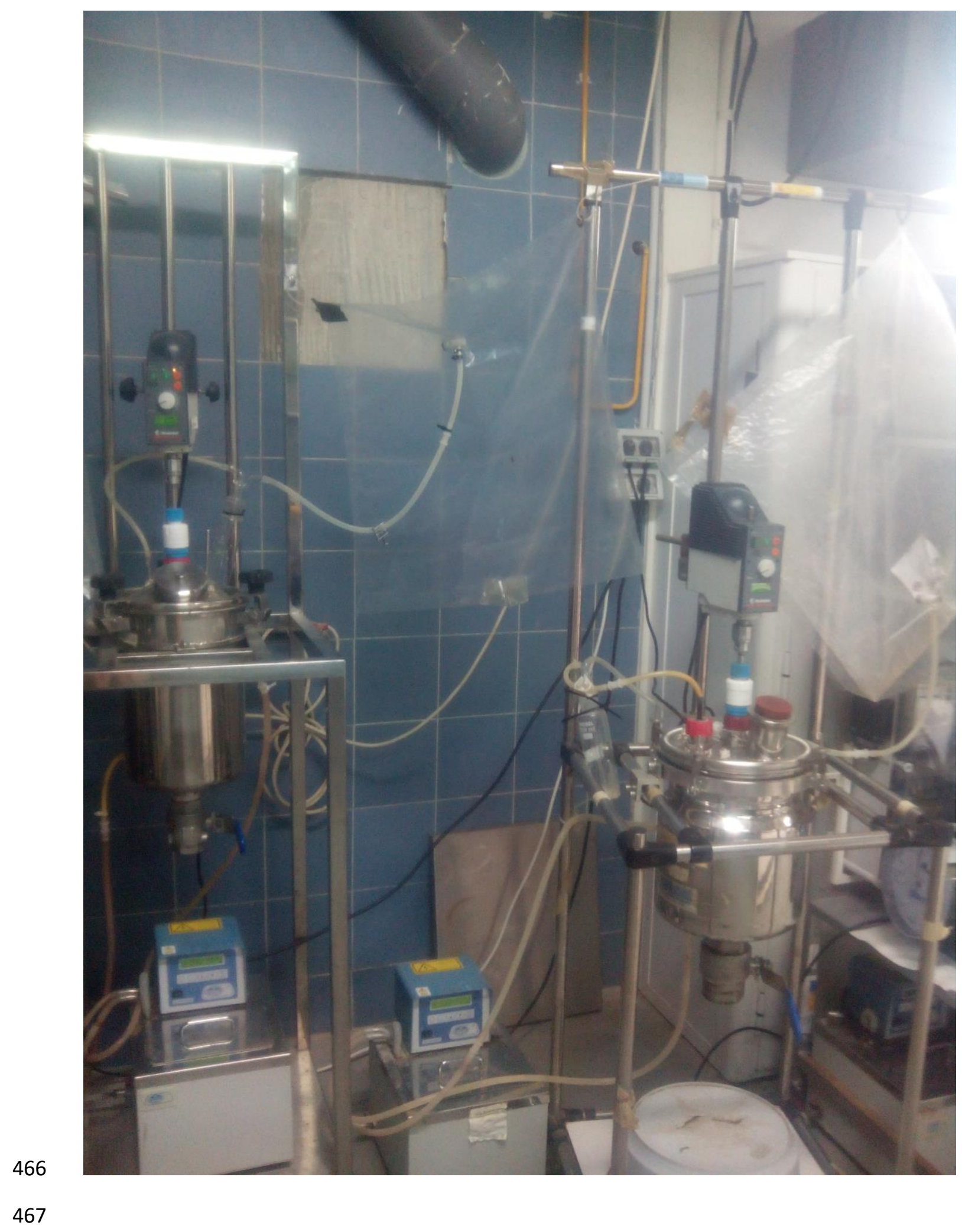


Figure 2a

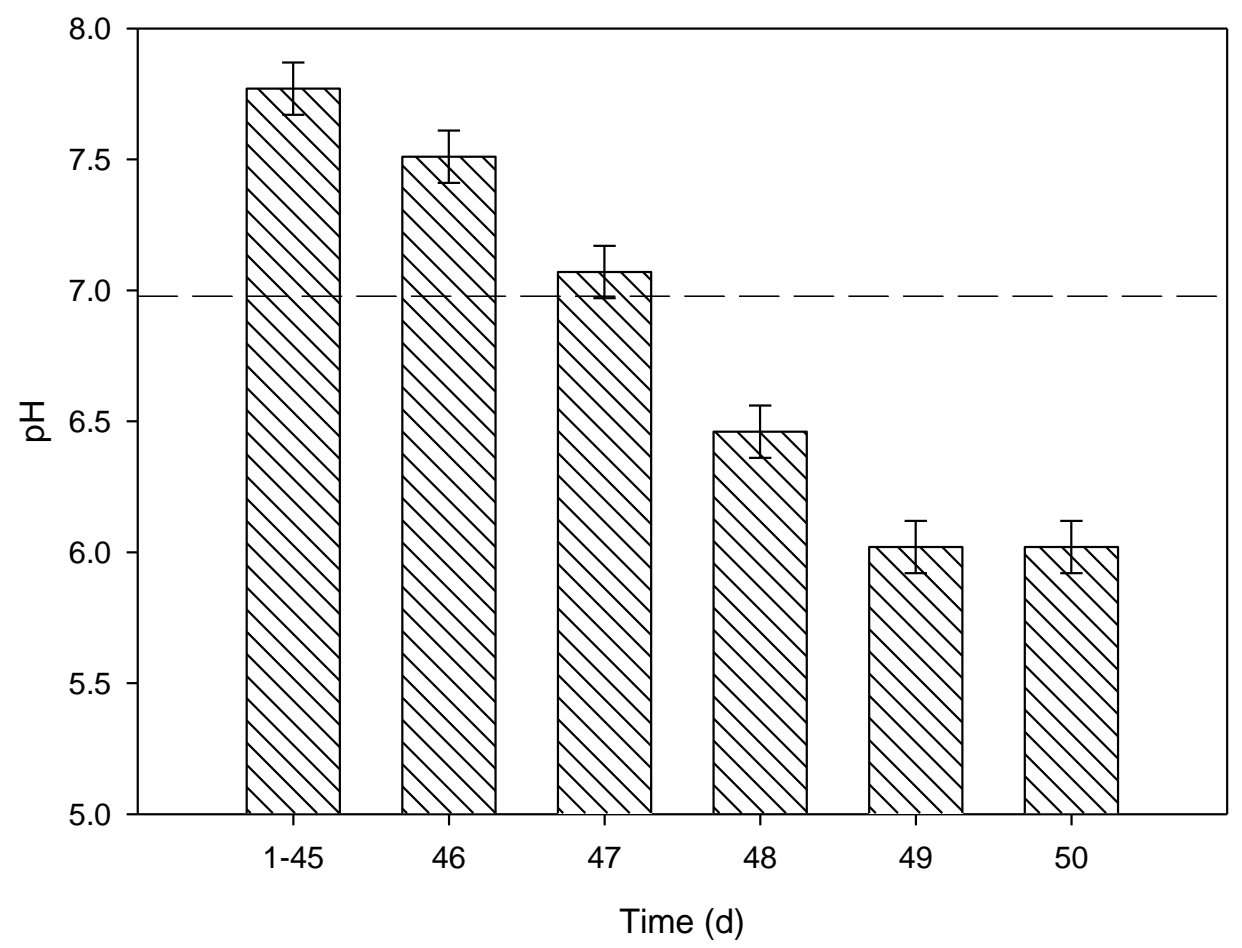

469

470 Figure 2.b

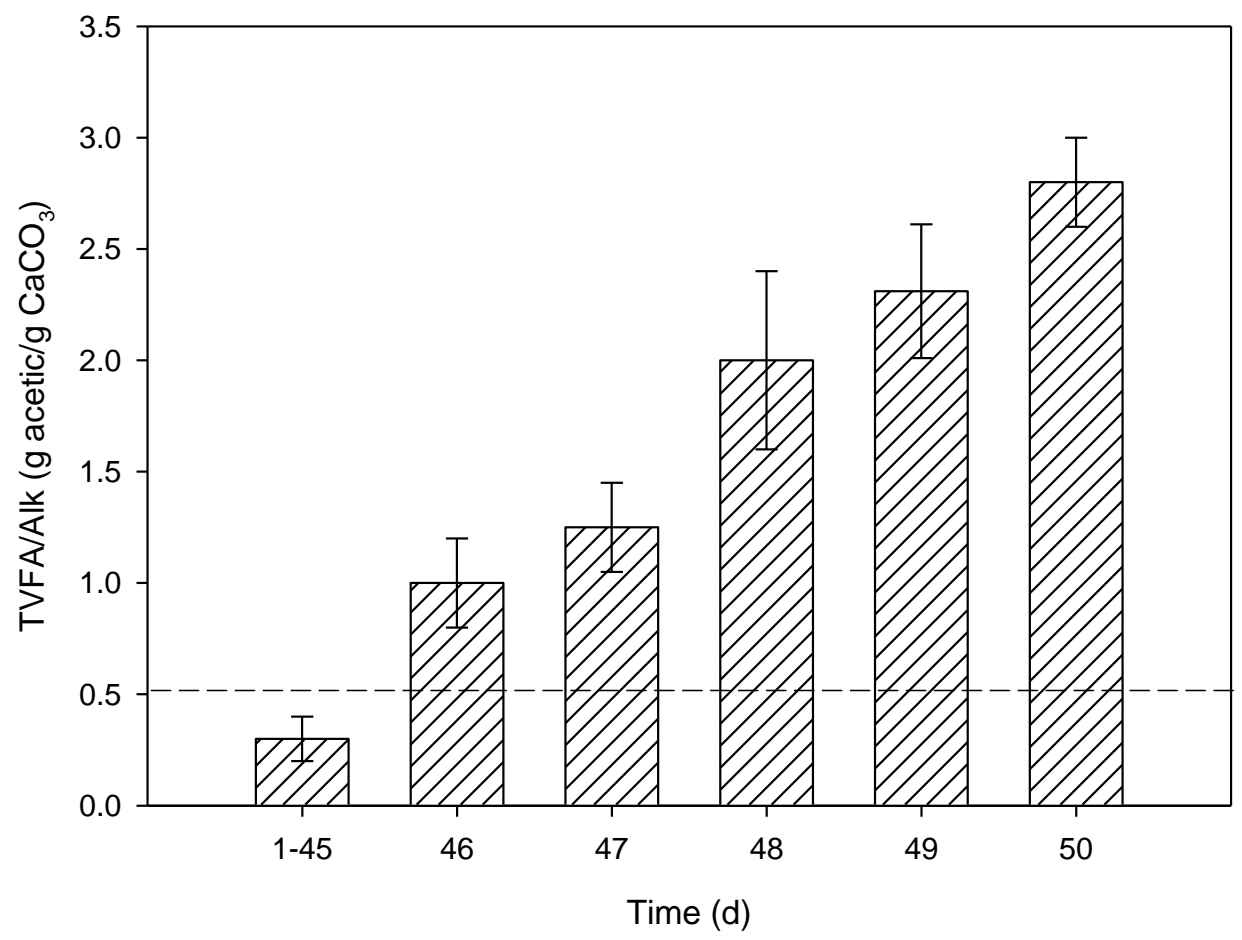

471 
Figure 3.a

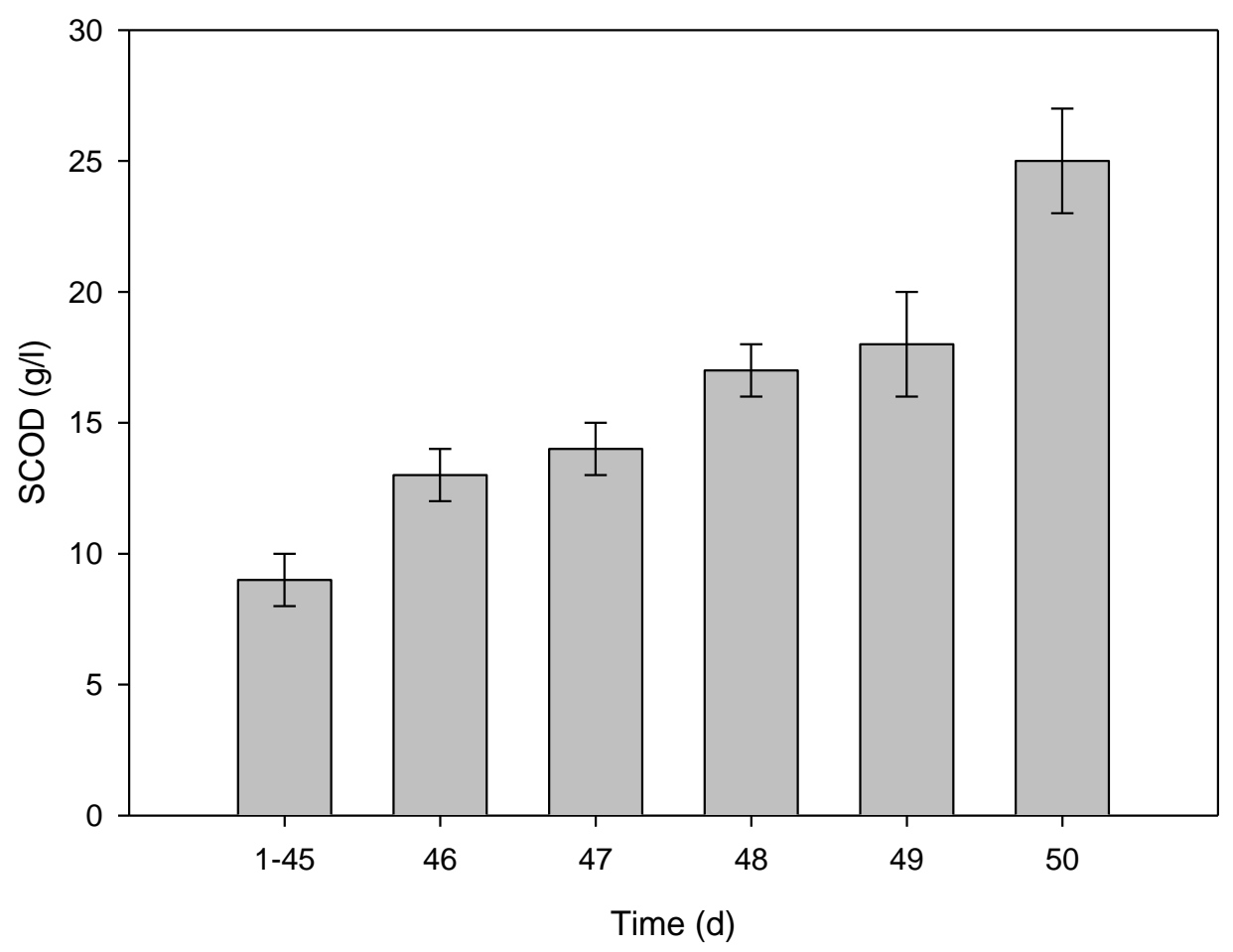

473

$474 \quad$ Figure 3.b

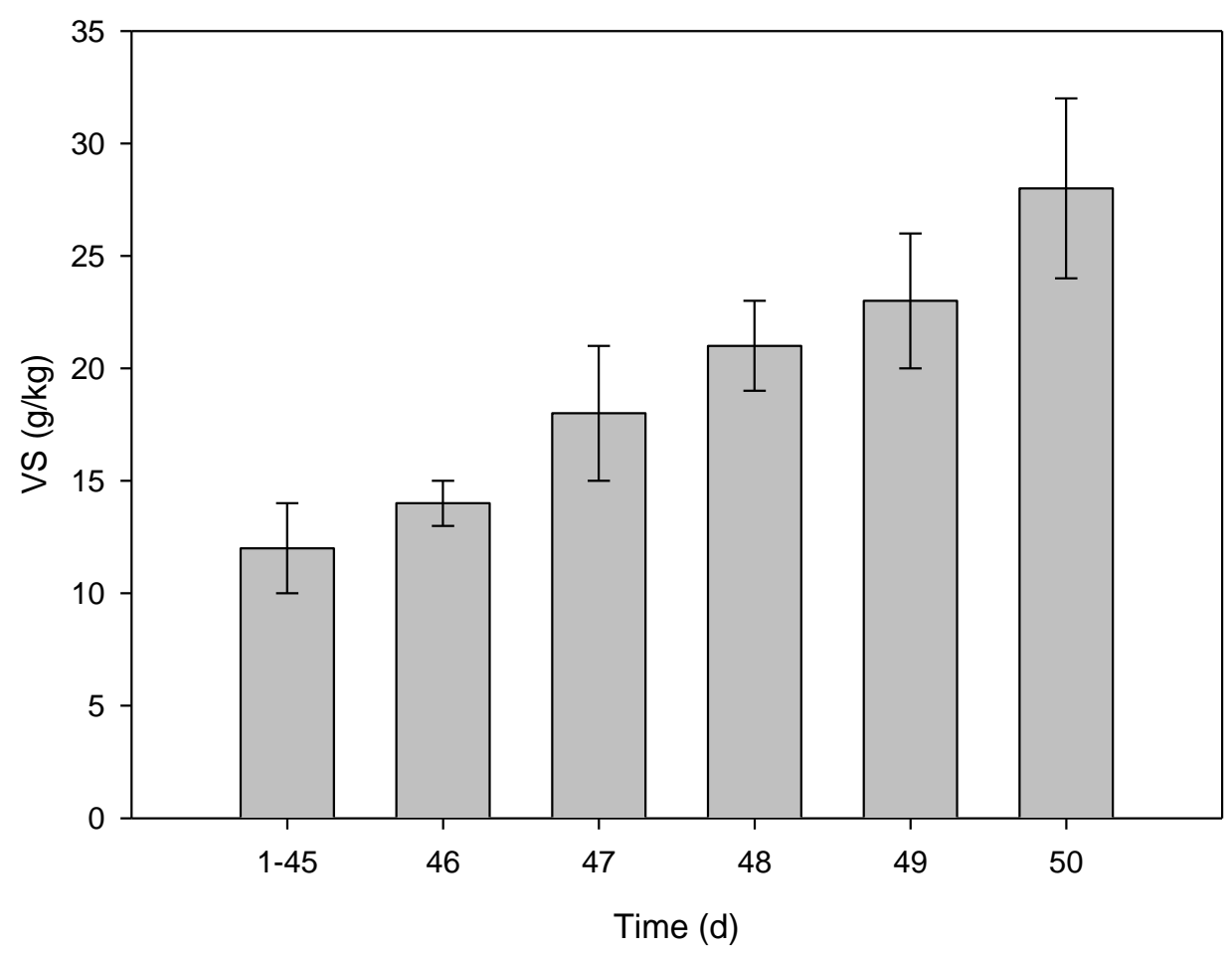


Figure 4

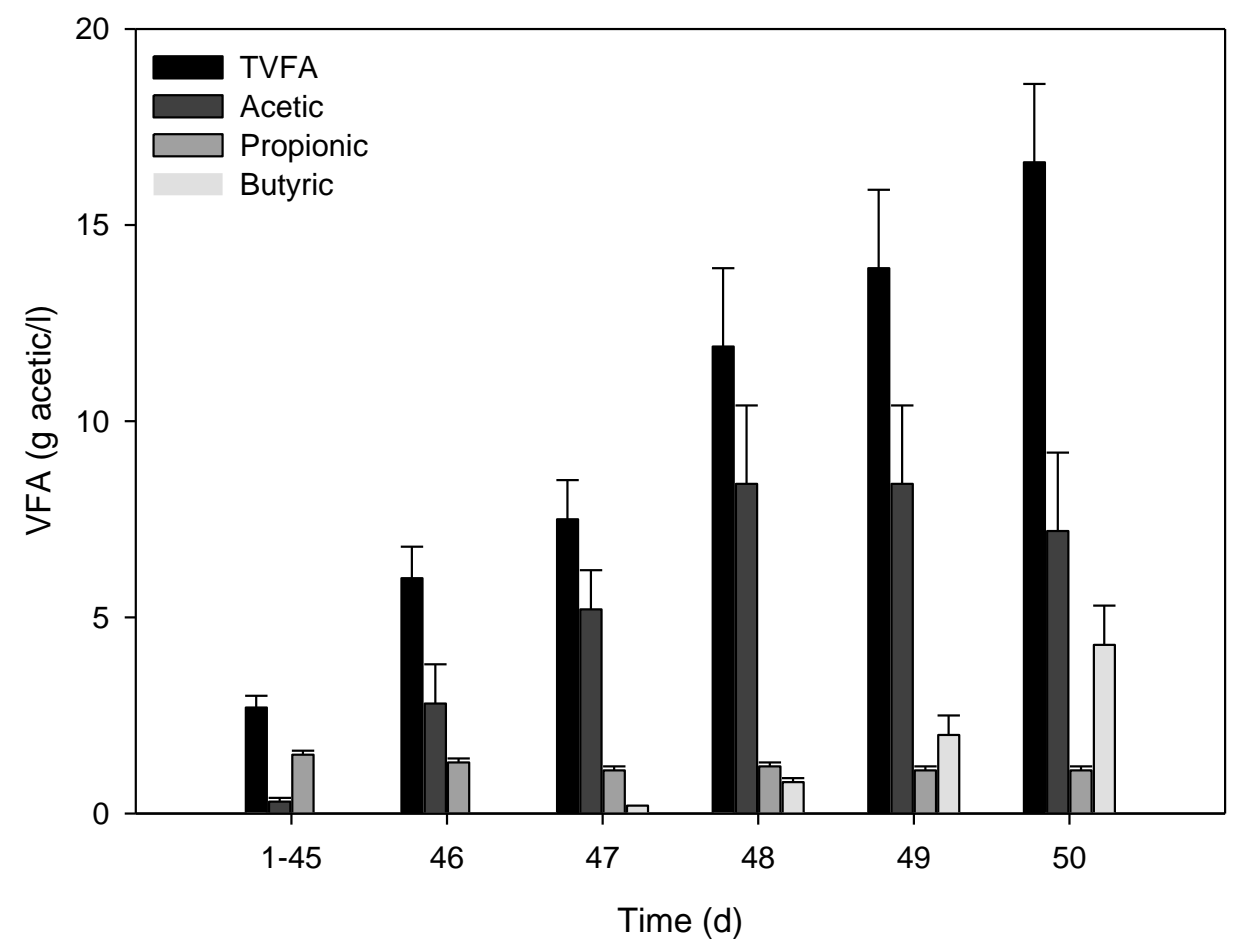

477 
$478 \quad$ Figure 5

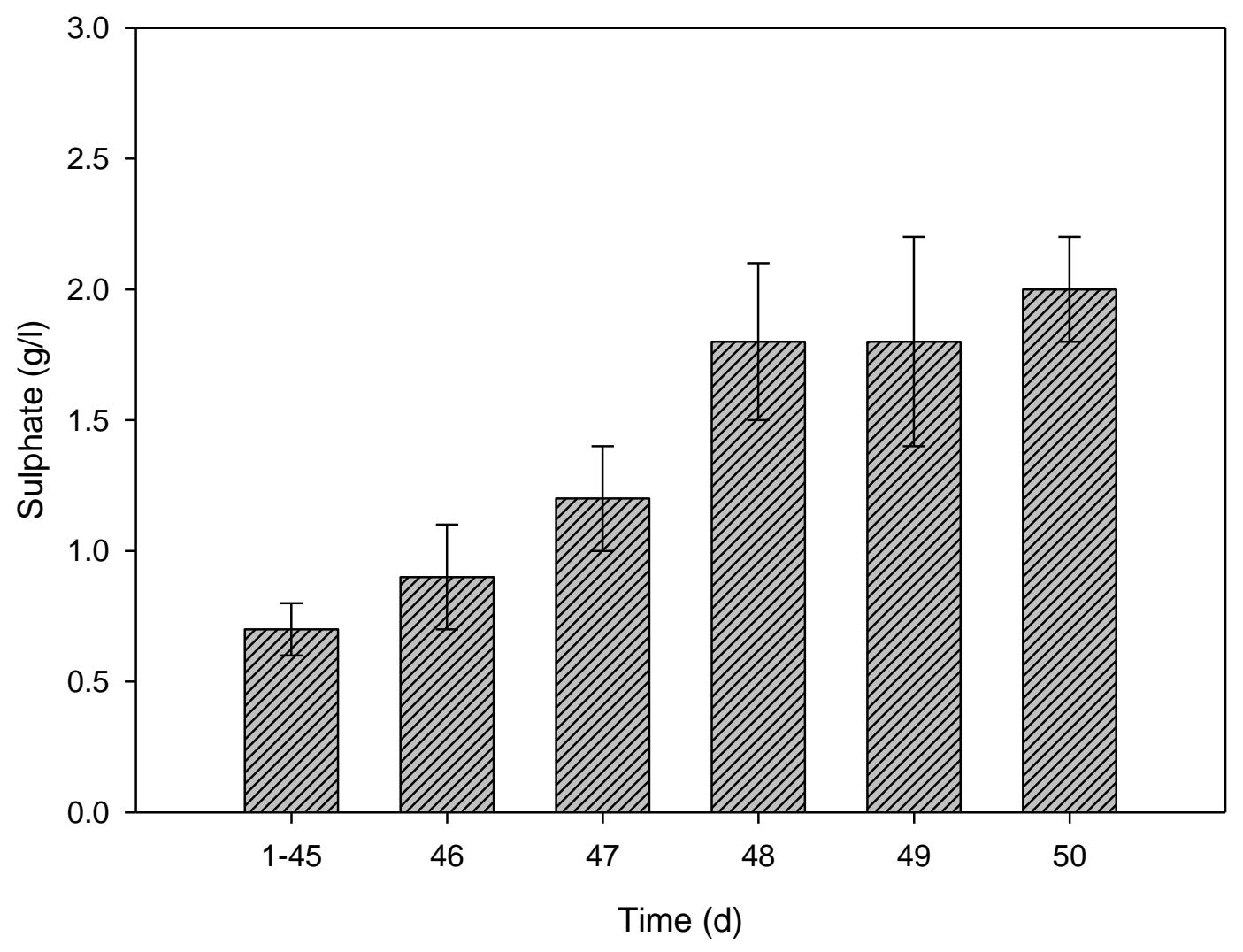

480

481 
482 Figure 6.a

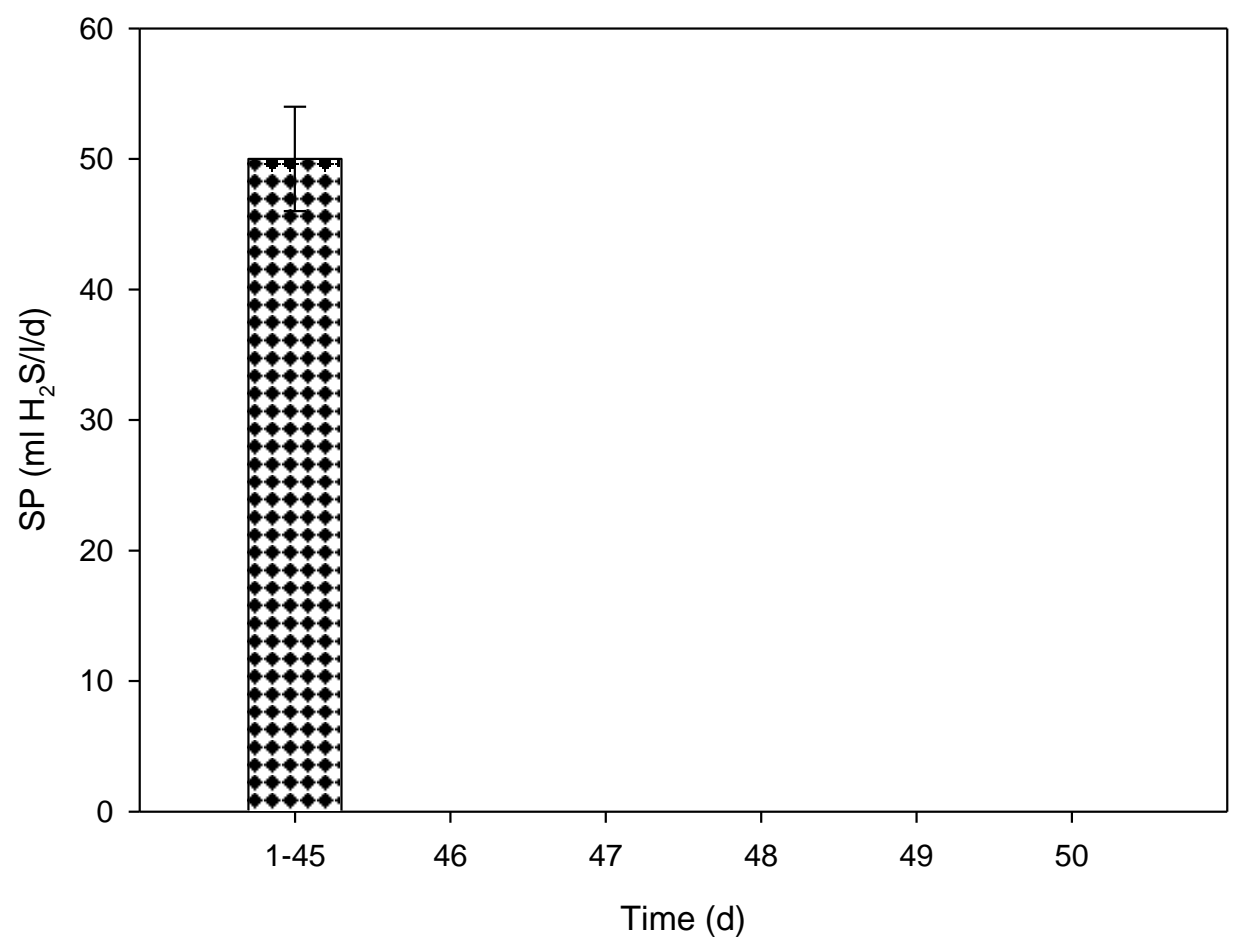

483

484

485 Figure 6.b

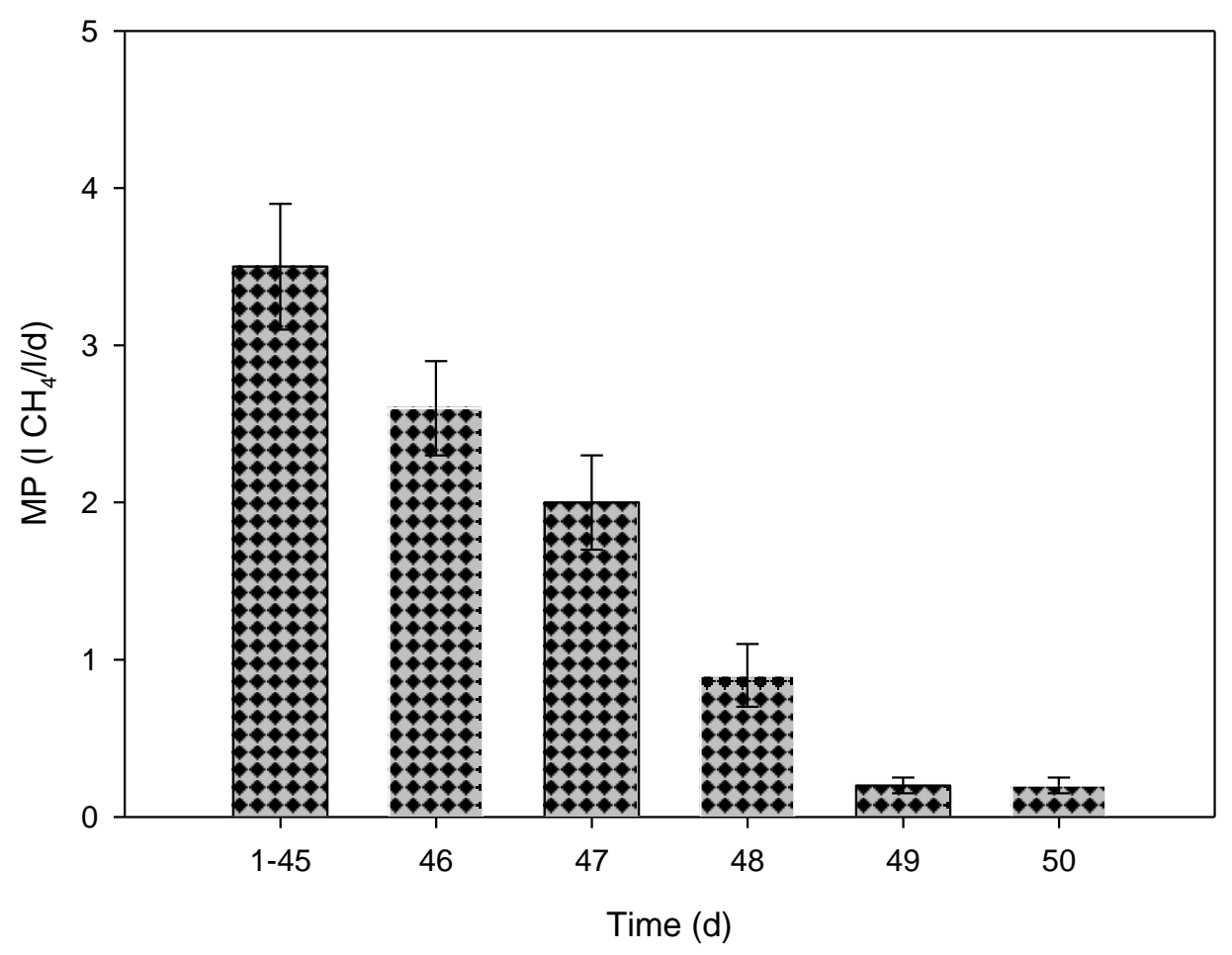

486 